Article

\title{
Development of Fluorescent Reagent Based on Ligand Exchange Reaction for the Highly Sensitive and Selective Detection of Dopamine in the Serum
}

\author{
Yoshio Suzuki \\ Health Research Institute, National Institute of Advanced Industrial Science and Technology (AIST), \\ 1-1-1 Higashi, Tsukuba, Ibaraki 305-8566, Japan; suzuki-yoshio@aist.go.jp; Tel.: +81-29-861-6122
}

Received: 6 August 2019; Accepted: 9 September 2019; Published: 12 September 2019

check for updates

\begin{abstract}
A new fluorescent probe (BDP- $\mathrm{Fe}^{2+}$ ) was developed for targeting dopamine, with a boron-dipyrromethenyl (BDP) group as the fluorophore and a $\mathrm{Fe}^{2+}$ complex as the ligand exchange site. The free form of $\mathbf{B D P}-\mathrm{Fe}^{2+}$ in solution displayed weak fluorescence emission, while it showed strong fluorescence emission after interaction with dopamine due to the release of $\mathrm{Fe}^{2+}$ from BDP- $\mathrm{Fe}^{2+}$, confirming the binding of $\mathrm{Fe}^{2+}$ to dopamine. The increase in fluorescence intensity was concentration-dependent, and a good linear relationship was observed between the fluorescence intensity and dopamine concentration. The detection limit of dopamine by BDP-Fe ${ }^{2+}$ was $1.1 \mathrm{nM}$, indicating a 20-fold higher sensitivity than that of previously reported compounds. The reaction of $\mathbf{B D P}-\mathrm{Fe}^{2+}$ with dopamine was not affected by the presence of foreign substances, allowing the highly selective detection of dopamine in the human serum sample. The results of this study indicate that the novel compound BDP-Fe ${ }^{2+}$ is a reliable fluorescent molecular probe for the detection of dopamine and can be widely employed in diverse scientific areas.
\end{abstract}

Keywords: fluorescence; dopamine; sensor; molecular probe; serum; high-throughput analysis

\section{Introduction}

Dopamine is an organic compound of the catecholamine and phenylethylamine families. Dopamine plays an important role as a neurotransmitter, and it is responsible for a wide range of cognitive functions, including motivation, behavior, learning, and memory. Its concentration affects emotions and reflects the state of one's health [1-3]. It greatly influences metabolism and plays a key role in maintaining central nervous system functions, including neuroplasticity, attention span, and memory, as well as various cardiovascular, hormonal, and renal functions [4]. Although dopamine itself is not a toxicant, it causes many diseases, including various diseases related to the human brain and neurological disorders such as Parkinson's disease; Parkinson's disease causes a reduction of dopaminergic neurons, and insufficient dopamine is then made in the human body. As a result, the movement of the body cannot be adjusted and is impaired; this disease increasingly affects the general population and is attracting considerable attention [5-8]. Consequently, there is an urgent need to develop efficient, rapid, sensitive, and selective methods for detecting dopamine and enabling the rapid development of related medication used in nerve physiology.

Various studies have been performed on the optical determination of dopamine from the viewpoint of the native fluorescence properties of dopamine, the efficiency of fluorescence quenching based on the reaction between dopamine and HRP (horseradish peroxidase), the utilization of quantum dots, and the derivatization of dopamine by ethylenediamine following oxidation using mercury(II) nitrate [9-14].

However, these methods are neither highly selective nor highly sensitive; instead, they are time-consuming and require further separation processes such as ion exchange chromatography, thin-layer chromatography, or high-performance liquid chromatography. 
The prerequisites considered in the present study to design a fluorescent reagent for dopamine detection were as follows:

1. The generation of a strong fluorescence signal after reaction with the target molecule;

2. The elimination of background noise for the highly sensitive detection of dopamine;

3. The reduction of interference from foreign substances for highly selective dopamine assay.

We have previously developed fluorometric reagents for the detection of various biological substances containing dopamine [15-21]. The interaction between the fluorescent reagent and dopamine caused the enhancement of fluorescence intensity due to the release of $\mathrm{Fe}^{2+}$ from the reagent and subsequent formation of a complex between $\mathrm{Fe}^{2+}$ and dopamine. However, the analysis using this fluorescent reagent had poor sensitivity and low photostability due to the chemical properties of the cyanopyranyl moiety, which could not be applicable in long-term analysis.

In this study, a new fluorescent molecular probe has been developed with the boron-dipyrromethenyl (BDP) group as the fluorescent emitter [22,23] and an imino-di-acetic acid-Fe ${ }^{2+}$ complex both as a fluorescent quencher and a ligand exchange moiety for the detection of dopamine. The BDP group has interesting spectral properties such as high quantum yields, large extinction coefficients, and high photostability-characteristics that satisfy the above concept of molecular design $[24,25]$. The chemical structures of the fluorescent reagents (BDP and its $\mathrm{Fe}^{2+}$ complex, BDP-Fe ${ }^{2+}$ ) are shown in Figure 1. The interactions of these molecules with dopamine were investigated, along with their selectivity, sensitivity, photostability, and detection in human serum samples. The results clearly indicated that BDP-Fe ${ }^{2+}$ acts as a reliable fluorescent probe, and it is useful for the high-throughput analysis of dopamine.

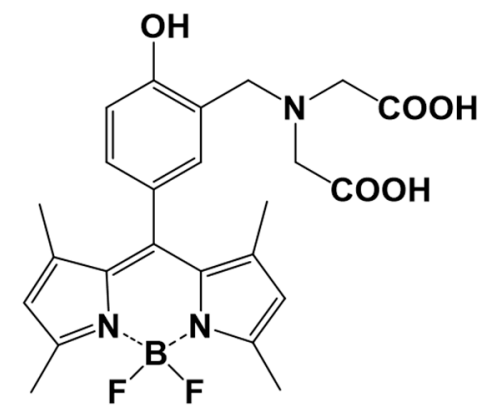

BDP

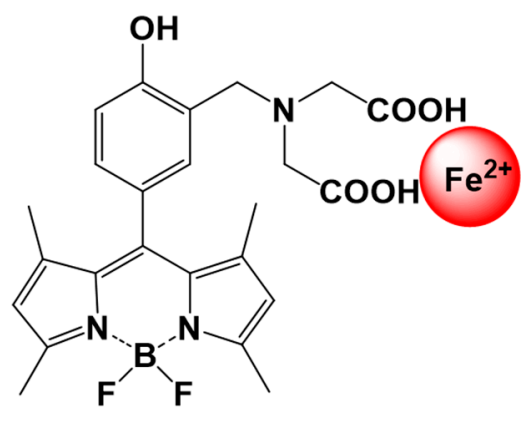

BDP-Fe ${ }^{2+}$

Figure 1. Chemical structures of the fluorescent reagents boron-dipyrromethenyl (BDP) and BDP-Fe ${ }^{2+}$.

\section{Materials and Methods}

\subsection{Chemicals, Materials, and Apparatus}

All the chemicals required for the synthesis and fluorometric measurements were of analytical grade and provided from Tokyo Chemical Industry (TCI, Tokyo, Japan), Wako Pure Chemical Industries, Ltd. (Osaka, Japan) and Sigma Aldrich (St. Louis, MO, USA). Absorption spectra were recorded at $25^{\circ} \mathrm{C}$ on a V-670 UV/Visible Spectrophotometer (JASCO, Tokyo, Japan). Fluorescence spectra were recorded at $25{ }^{\circ} \mathrm{C}$ on a JASCO FP-6500 fluorophotometer and an FMP-825 microplate reader. ${ }^{1} \mathrm{H}$ nuclear magnetic resonance (NMR) spectra were recorded on a Bruker AV-500 spectrometer.

\subsection{Measurements}

The compound BDP-Fe ${ }^{2+}$ was dissolved in 4-(2-hydroxyethyl)-1-piperazineethanesulfonic acid (HEPES) buffer solution ( $\mathrm{pH} 7.0$ ) to obtain a final concentration of $1.0 \mu \mathrm{M}$. After the addition of $1.0 \mathrm{~mL}$ of dopamine or foreign substance solution to $1.0 \mathrm{~mL}$ of $\mathrm{BDP}-\mathrm{Fe}^{2+}$ solution, the reaction mixture was incubated for $5 \mathrm{~min}$, and fluorescence spectra were recorded. 


\subsection{Synthesis of the Ligand}

The synthesis of the fluorescent reagent is illustrated in Scheme 1 . The protocols for the synthesis of diethyl-2,2'-(5-formyl-2-hydroxybenzylazanediyl)diacetate have been reported previously [19]. The individual synthetic protocols are described below.

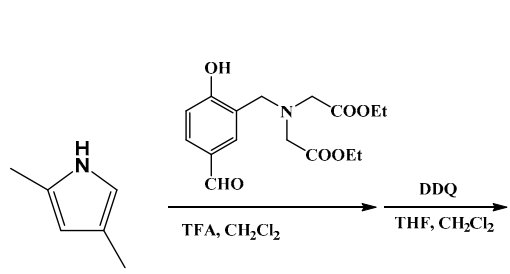

2

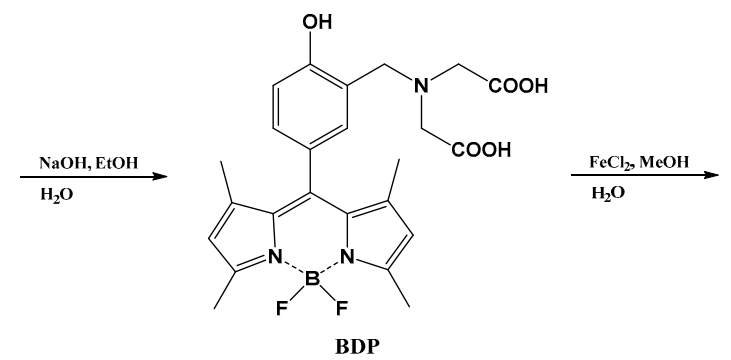

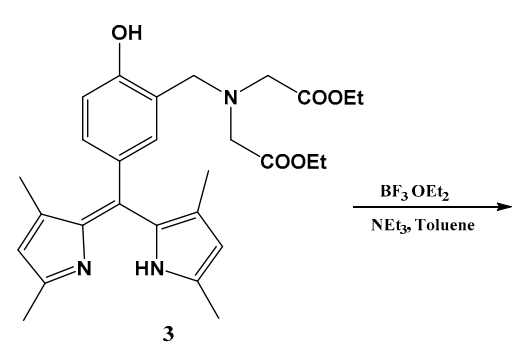
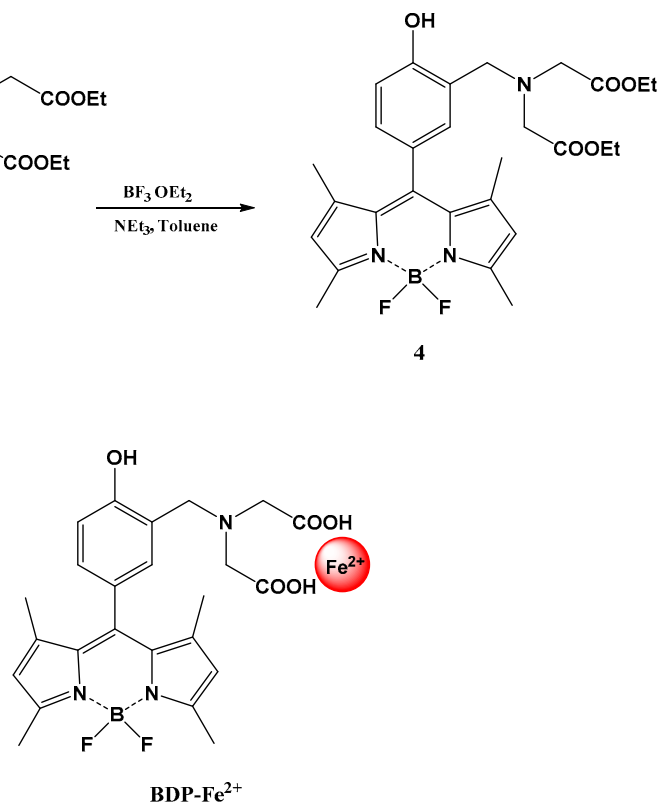

Scheme 1. Method for the synthesis of the BDP-Fe ${ }^{2+}$.

2.3.1. Diethyl 2,2'-((5-((3,5-dimethyl-1H-pyrrol-2-yl)(3,5-dimethyl-2H-pyrrol-2-ylidene)methyl)2-hydroxybenzyl)azanediyl)(Z)-diacetate

Anhydrous dichloromethane $(40 \mathrm{~mL})$ and 2,4-dimethyl pyrrole $(2.5 \mathrm{~g}, 26.4 \mathrm{mmol})$ were added to a solution of diethyl-2,2'-(5-formyl-2-hydroxybenzylazanediyl)-diacetate ( $2.2 \mathrm{~g}, 13.2 \mathrm{mmol}$ ) and stirred for $30 \mathrm{~min}$ in an $\mathrm{N}_{2}$ atmosphere. After the addition of trifluoroacetic acid $(0.5 \mathrm{~mL}, 6.5 \mathrm{mmol})$, the reaction mixture was stirred for $24 \mathrm{~h}$ at room temperature. 2,3-Dichloro-5,6-dicyano-1,4-benzoquinone (5.97 g, $26.26 \mathrm{mmol})$, dissolved in a mixture of anhydrous THF $(25 \mathrm{~mL})$ and anhydrous dichloromethane $(25 \mathrm{~mL})$, was added dropwise over $15 \mathrm{~min}$ to the mixture, which was then stirred for $4 \mathrm{~h}$ at room temperature. Saturated aqueous $\mathrm{NaHCO}_{3}$ solution was added and the mixture was extracted with dichloromethane. The organic layer was washed with water and brine, dried over $\mathrm{Na}_{2} \mathrm{SO}_{4}$, and concentrated in vacuo. The crude product was purified by column chromatography $\left(\mathrm{SiO}_{2}, n\right.$-hexane:ethyl acetate:triethylamine $=49: 49: 2 \mathrm{v} / \mathrm{v})$ to obtain a brown solid with $27.5 \%$ yield.

${ }^{1} \mathrm{H}$ NMR $\left(\mathrm{CDCl}_{3}, 500 \mathrm{MHz}\right.$, r.t., TMS, $\left.\delta / \mathrm{ppm}\right) 1.24(6 \mathrm{H}, \mathrm{t}), 1.27(6 \mathrm{H}, \mathrm{s}), 2.34(6 \mathrm{H}, \mathrm{s}), 3.53(4 \mathrm{H}, \mathrm{s}), 4.04$ $(2 \mathrm{H}, \mathrm{s}), 4.21(4 \mathrm{H}, \mathrm{q}), 5.88(2 \mathrm{H}, \mathrm{s}), 6.99(1 \mathrm{H}, \mathrm{d}), 7.57(1 \mathrm{H}, \mathrm{s}), 7.75(1 \mathrm{H}, \mathrm{d}), 10.54(1 \mathrm{H}, \mathrm{bs})$.

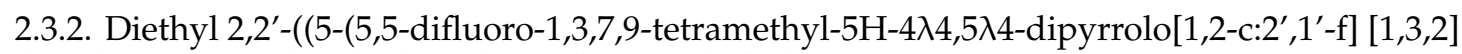
diazaborinin-10-yl)-2-hydroxybenzyl) azanediyl) diacetate

Diethyl 2,2'-((5-((3,5-dimethyl-1H-pyrrol-2-yl) (3,5-dimethyl-2H-pyrrol-2-ylidene)methyl)-2hydroxybenzyl) azanediyl) (Z)-diacetate $(1.6 \mathrm{~g}, 4.78 \mathrm{mmol})$ was dissolved in anhydrous toluene $(65 \mathrm{~mL})$, triethylamine $(9.2 \mathrm{~mL})$, and $\mathrm{BF}_{3} \bullet \mathrm{Et}_{2} \mathrm{O}(9.2 \mathrm{~mL})$. The mixture was stirred for $3 \mathrm{~h}$ at room temperature. Saturated aqueous $\mathrm{NaHCO}_{3}$ solution was added and the mixture extracted with $\mathrm{CH}_{2} \mathrm{Cl}_{2}$. The organic layer was washed with brine, dried over $\mathrm{Na}_{2} \mathrm{SO}_{4}$, and concentrated in vacuo. The crude product was purified by column chromatography $\left(\mathrm{SiO}_{2}, n\right.$-hexane:ethyl acetate $\left.=1: 1 \mathrm{v} / \mathrm{v}\right)$ to obtain a brown solid in $95.8 \%$ yield.

${ }^{1} \mathrm{H}$ NMR $\left(\mathrm{CDCl}_{3}, 500 \mathrm{MHz}\right.$, r.t., TMS, $\left.\delta / \mathrm{ppm}\right) 1.25(6 \mathrm{H}, \mathrm{t}), 1.36(6 \mathrm{H}, \mathrm{s}), 2.55(6 \mathrm{H}, \mathrm{s}), 3.54(4 \mathrm{H}, \mathrm{s}), 4.03$ $(2 \mathrm{H}, \mathrm{s}), 4.22(4 \mathrm{H}, \mathrm{q}), 5.95(2 \mathrm{H}, \mathrm{s}), 6.98(1 \mathrm{H}, \mathrm{d}), 7.58(1 \mathrm{H}, \mathrm{s}), 7.76(1 \mathrm{H}, \mathrm{d}), 10.55(1 \mathrm{H}, \mathrm{bs})$. 


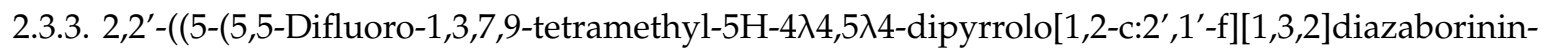
10-yl)-2-hydroxybenzyl)azanediyl) diacetic acid (BDP)

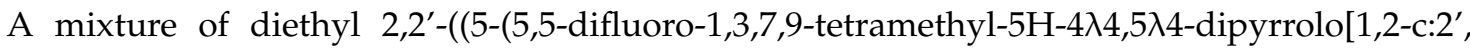
$1^{\prime}$-f][1,3,2], diazaborinin-10-yl)-2-hydroxybenzyl) azanediyl) diacetate ( $\left.0.5 \mathrm{~g}, 1.31 \mathrm{mmol}\right)$, and sodium hydroxide $(0.30 \mathrm{~g}, 2.17 \mathrm{mmol})$ in EtOH-water $(40 \mathrm{~mL}-10 \mathrm{~mL})$ was stirred for $24 \mathrm{~h}$ at room temperature. After the removal of $\mathrm{EtOH}$, the solution was acidified to $\mathrm{pH} 6.0$ using $1 \mathrm{~N} \mathrm{HCl}$, extracted with ethyl acetate, and dried over $\mathrm{Na}_{2} \mathrm{SO}_{4}$. The solvent was evaporated in vacuo. The brown solid obtained in $96.2 \%$ yield was used without further purification.

${ }^{1} \mathrm{H}$ NMR $\left(\mathrm{CD}_{3} \mathrm{OD}, 500 \mathrm{MHz}\right.$, r.t., TMS, $\left.8 / \mathrm{ppm}\right) 1.37(6 \mathrm{H}, \mathrm{s}), 2.56(6 \mathrm{H}, \mathrm{s}), 3.55(4 \mathrm{H}, \mathrm{s}), 4.04(2 \mathrm{H}, \mathrm{s})$, $5.96(2 \mathrm{H}, \mathrm{s}), 6.99(1 \mathrm{H}, \mathrm{d}), 7.57(1 \mathrm{H}, \mathrm{s}), 7.75(1 \mathrm{H}, \mathrm{d}), 10.54(1 \mathrm{H}, \mathrm{bs})$.

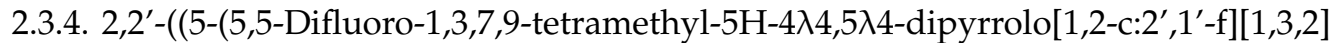

diazaborinin-10-yl)-2-hydroxybenzyl)azanediyl)diacetic acid $\mathrm{Fe}(\mathrm{II})$ complex (BDP-Fe ${ }^{2+}$ )

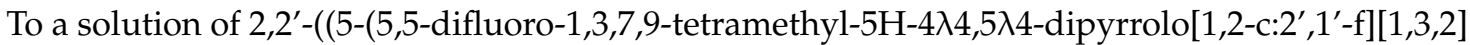
diazaborinin-10-yl)-2-hydroxybenzyl)azanediyl)diacetic acid $(84.1 \mathrm{mg}, 0.13 \mathrm{mmol})$ in methanol $(20 \mathrm{~mL})$, $100 \mathrm{mM} \mathrm{FeCl}{ }_{2}$ aqueous solution $(1.3 \mathrm{~mL})$ was added, and the mixture was stirred for $1 \mathrm{~h}$ at room temperature. After solvent removal, the residue was dried, and the product was recovered as a brown solid in $98 \%$ yield.

$$
\operatorname{ESI-MS~(+):~}[\mathrm{M}]^{2+}=271.05
$$

\section{Results and Discussion}

The excitation and emission spectra of BDP were recorded in a buffer solution $(\mathrm{pH} 7.0)$ at $25^{\circ} \mathrm{C}$ to study the photophysical properties in vitro. Typical excitation and emission spectra of BDP are shown in Figure 2, with excitation and emission maxima at $496 \mathrm{~nm}$ and $525 \mathrm{~nm}$, respectively. This result was consistent with the typical excitation and emission maxima of a BDP fluorophore.

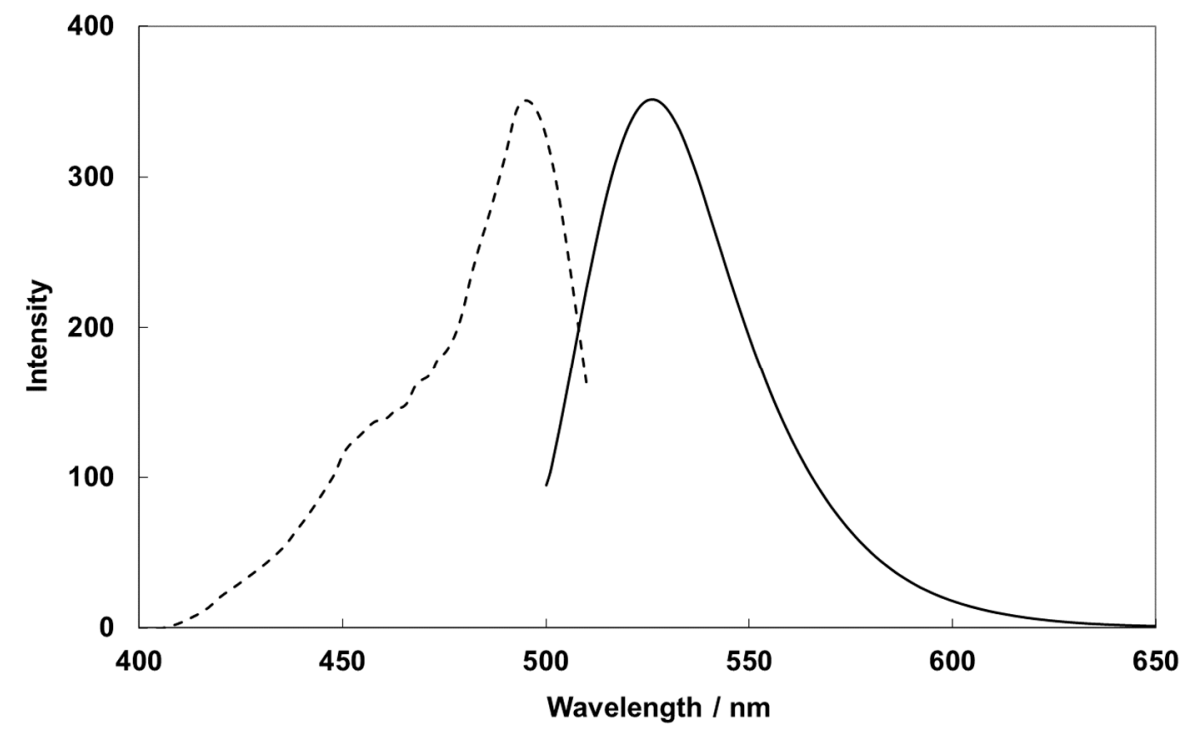

Figure 2. Excitation (dotted line) and emission spectra (solid line) of BDP; $[\mathrm{BDP}]=1.0 \mu \mathrm{M}$; solvent $=20.0 \mathrm{mM}$ HEPES buffer $\quad(\mathrm{pH}$ 7.0); excitation wavelength $=490 \mathrm{~nm}$, monitored wavelength $=525 \mathrm{~nm}$.

To study the reaction of $\mathrm{Fe}^{2+}$ with $\mathrm{BDP}$, fluorescence spectra were investigated, and the signal was monitored by mixing BDP $(1.0 \mu \mathrm{M})$ with $\mathrm{Fe}^{2+}(5.0 \mu \mathrm{M})$ in HEPES $(20.0 \mathrm{mM} ; \mathrm{pH} 7.2)$ to form BDP-Fe ${ }^{2+}$. The fluorescence intensities of BDP decreased following the addition of $\mathrm{Fe}^{2+}$ due to the considerable quenching effect, as shown in Figure 3. Other metal cations $\left(\mathrm{Ni}^{2+}, \mathrm{Co}^{2+}, \mathrm{Cu}^{2+}, \mathrm{Mn}^{2+}, \mathrm{Zn}^{2+}, \mathrm{Li}^{+}\right.$, 
$\mathrm{Na}^{+}, \mathrm{K}^{+}, \mathrm{Cs}^{+}, \mathrm{Mg}^{2+}, \mathrm{Ca}^{2+}, \mathrm{Ba}^{2+}$, and $\mathrm{Pb}^{2+}$ ) were added to the solution of $\mathrm{BDP}$, and the fluorescence intensities were monitored. The observed order of the fluorescence intensity was as follows: $\mathrm{Fe}^{2+}(6.5)$ $>\mathrm{Ni}^{2+}(25.0)>\mathrm{Co}^{2+}(156.0)>\mathrm{Cu}^{2+}(201.5)>\mathrm{Mn}^{2+}(250.2)>\mathrm{Zn}^{2+}$ (292.3). Fluorescence quenching did not take place for alkali metal ions, alkaline earth metal ions, and $\mathrm{Pb}^{2+}$, as shown in Figure $3 \mathrm{~b}$. Thus, $\mathrm{Fe}^{2+}$ was a particularly strong quencher of BDP fluorescence. To take advantage of this phenomena, the BDP- $\mathrm{Fe}^{2+}$ complex was used in this study, because we used the ligand exchange mechanism, and a large fluorescence enhancement from quenching state was requested, enabling the highly sensitive detection of dopamine by the dissociation of $\mathrm{Fe}^{2+}$ from BDP-Fe ${ }^{2+}$.
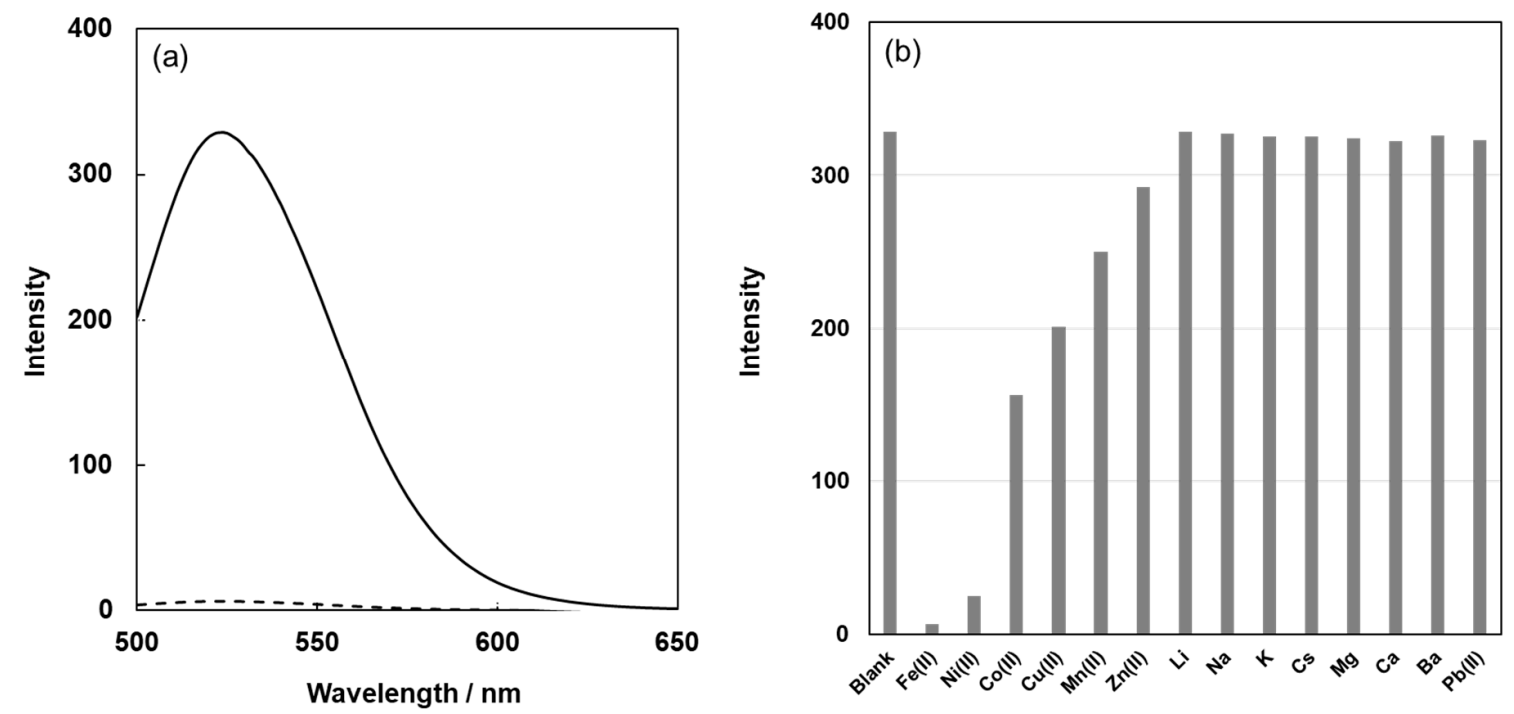

Figure 3. Fluorescence spectra of BDP (solid line) and its $\mathrm{Fe}^{2+}$ complex, BDP-Fe ${ }^{2+}$ (dotted line) recorded at room temperature (a), and the fluorescence intensity of BDP at $525 \mathrm{~nm}$ before and after the addition of various metal ions such as $\mathrm{Fe}^{2+}, \mathrm{Ni}^{2+}, \mathrm{Co}^{2+}, \mathrm{Cu}^{2+}, \mathrm{Mn}^{2+}, \mathrm{Zn}^{2+}, \mathrm{Li}^{+}, \mathrm{Na}^{+}, \mathrm{K}^{+}, \mathrm{Cs}^{+}$, $\mathrm{Mg}^{2+}, \mathrm{Ca}^{2+}, \mathrm{Ba}^{2+}$, and $\mathrm{Pb}^{2+}(\mathbf{b}) .[\mathrm{BDP}]=1.0 \mu \mathrm{M}$; solvent = HEPES buffer solution ( $\mathrm{pH} 7.0$ ); excitation wavelength $=490 \mathrm{~nm}$.

Fluorimetric titrations were performed with dopamine by using BDP- $\mathrm{Fe}^{2+}$ to investigate the ligand exchange reaction. The concentration of $\mathrm{BDP}-\mathrm{Fe}^{2+}$ was $1.0 \mu \mathrm{M}$ and that of the dopamine solutions varied between 0 and $5.0 \mu \mathrm{M}$ in HEPES buffer solutions (20.0 mM, pH 7.2). The data are shown in Figure 4 . As is evident from the data, the fluorescence enhancement following the addition of dopamine was remarkable. The fluorescence intensity signal was saturated at a dopamine concentration of $>4.0 \mu \mathrm{M}$, and the numerical values of the fluorescence intensity of BDP- $\mathrm{Fe}^{2+}$ increased from 6.4 (free form) at $525 \mathrm{~nm}$ to $328.9 \mathrm{~nm}$ following the reaction with $5.0 \mu \mathrm{M}$ of dopamine, corresponding to a 51.4-fold increase in fluorescence intensity. The detection limit was determined to be $1.1 \mathrm{nM}$ of dopamine, which was calculated from the baseline noise $(\mathrm{S} / \mathrm{N}=3)$. The detection limit of the previously reported compound is $10.0 \mathrm{nM}$ [19], indicating 10-fold poorer sensitivity than that of BDP-Fe ${ }^{2+}$. These observations indicate that the $\mathrm{BDP}-\mathrm{Fe}^{2+}$ containing a dipyrromethenyl group shows brighter fluorescence and large fluorescence enhancement after reaction with dopamine, thereby improving sensitivity. Thus, the chemical structures of the fluorophore in $\mathrm{BDP}-\mathrm{Fe}^{2+}$ play an important role in the detection of dopamine.

Figure 5 shows the reaction time dependence of the fluorescence intensity at $525 \mathrm{~nm}$ of BDP-Fe ${ }^{2+}$ with dopamine. The fluorescence intensity saturated after 3.0 5.0 $\mathrm{min}$, and $5.0 \mathrm{~min}$ was considered optimal for the reaction between BDP- $\mathrm{Fe}^{2+}$ and dopamine. 

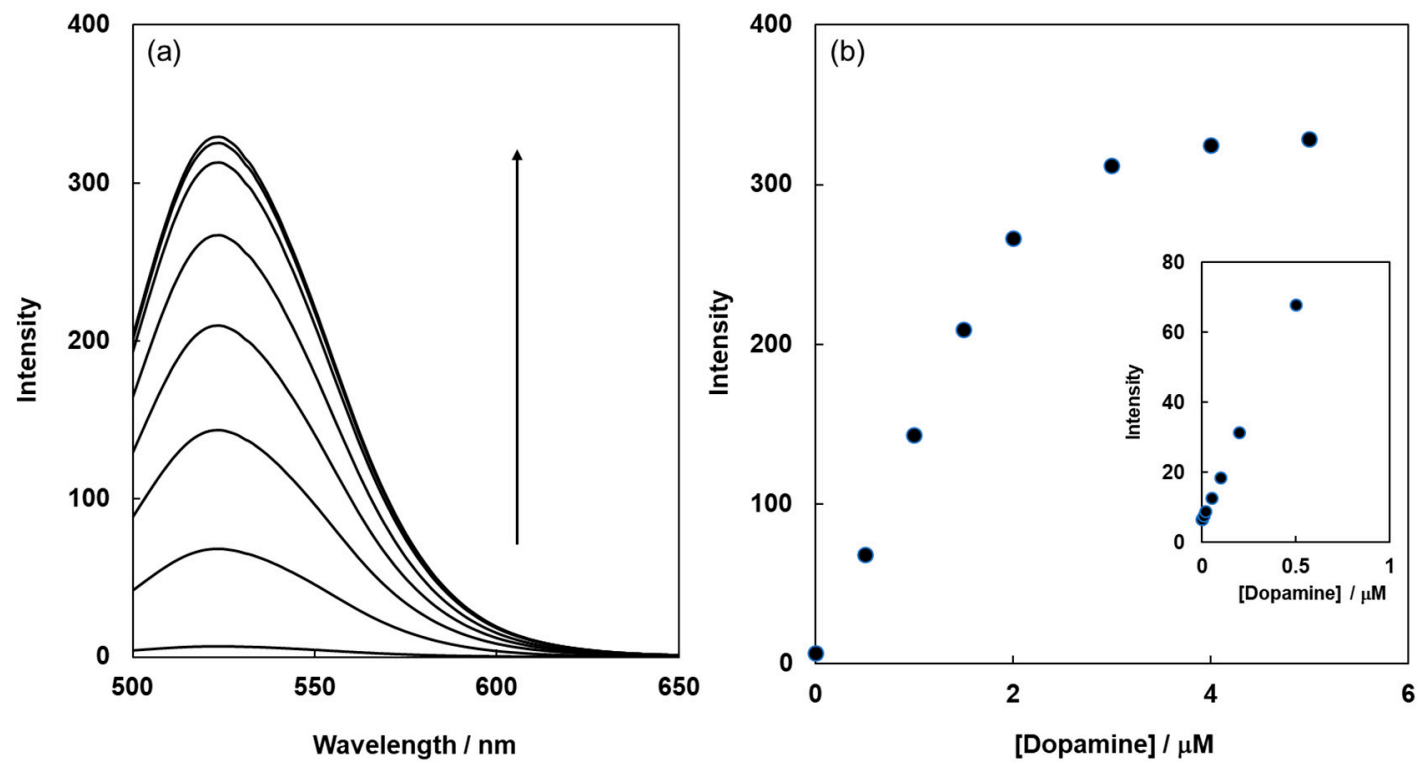

Figure 4. Fluorescence spectra of BDP-Fe ${ }^{2+}$ before and after dopamine addition, recorded at room temperature (a), and fluorescence intensity of ${\mathrm{BDP}-\mathrm{Fe}^{2+}}^{2}$ at $525 \mathrm{~nm}$ following dopamine addition at different concentrations (b); $\left[\mathrm{BDP}-\mathrm{Fe}^{2+}\right]=1.0 \mu \mathrm{M}$; solvent = HEPES buffer solution ( $\mathrm{pH} 7.0$ ); excitation wavelength $=490 \mathrm{~nm}$.

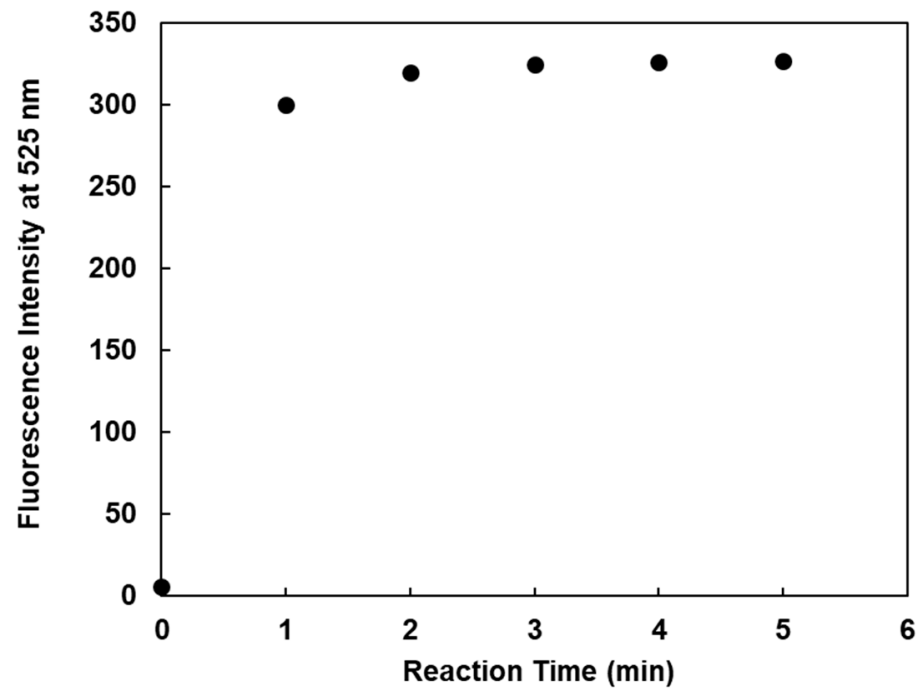

Figure 5. Variation of the fluorescence ratio of $\mathrm{BDP}-\mathrm{Fe}^{2+}$ at $525 \mathrm{~nm}$ with time after dopamine addition. $\left[\mathrm{BDP}^{-\mathrm{Fe}^{2+}}\right]=1.0 \mu \mathrm{M}$; [Dopamine $]=5.0 \mu \mathrm{M}$; solvent = HEPES buffer solution $(\mathrm{pH} 7.0)$; excitation wavelength $=490 \mathrm{~nm}$.

In order to understand how $\mathrm{pH}$ affects the reaction between $\mathrm{BDP}-\mathrm{Fe}^{2+}$ and dopamine, fluorescence signals were monitored at different $\mathrm{pH}$ values. Figure 6 shows the fluorescence intensity at $525 \mathrm{~nm}$ of

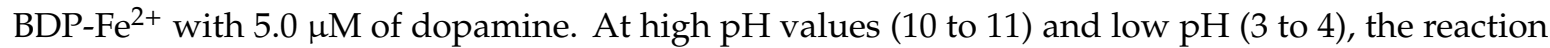
of BDP-Fe ${ }^{2+}$ with dopamine was inhibited by the solution $\mathrm{pH}$, whereas the fluorescence intensity was nearly unchanged when the $\mathrm{pH}$ was in the range 5-9. As a result, the reaction of $\mathrm{BDP}-\mathrm{Fe}^{2+}$ with dopamine was neither inhibited nor masked at a physiological level of $\mathrm{pH}$ values, and this assay should be appropriate to monitor the quantitative analysis of dopamine under such conditions.

To investigate the role of $\mathrm{Fe}^{2+}$ in $\mathrm{BDP}-\mathrm{Fe}^{2+}$ for the detection of dopamine, the fluorescent properties of the free form of BDP (not $\mathrm{Fe}^{2+}$ complex), were monitored before and after the addition of dopamine $(0$ to $5.0 \mu \mathrm{M})$. Fluorescence intensities of BDP at $525 \mathrm{~nm}$ hardly changed after the addition of dopamine, 
as shown in Figure 7. Moreover, other transition metal complexes $\left(B D P-\mathrm{M}^{2+}\left(\mathrm{M}^{2} \mathrm{Ni}^{2+}, \mathrm{Co}^{2+}, \mathrm{Cu}^{2+}\right.\right.$, $\left.\mathrm{Mn}^{2+}, \mathrm{Zn}^{2+}\right)$ ) did not show any response after the addition of dopamine because no reaction occurred between these metals and the dopamine [19]. On the other hand, BDP-Fe ${ }^{2+}$ indicated significant fluorescence enhancement after the reaction with dopamine. From these results, $\mathrm{Fe}^{2+}$ in $\mathrm{BDP}-\mathrm{Fe}^{2+}$ plays an important role in the detection of dopamine, and schematic representations of the reaction between $\mathrm{BDP}-\mathrm{Fe}^{2+}$ dopamine are illustrated in Figure 8. The free form of BDP-Fe ${ }^{2+}$ emitted remarkably weak fluorescence, whereas the fluorescence enhancement by the interaction of $\mathrm{BDP}-\mathrm{Fe}^{2+}$ with dopamine can be considered to be the release of $\mathrm{Fe}^{2+}$ from $\mathrm{BDP}-\mathrm{Fe}^{2+}$, and the dopamine coordinated with $\mathrm{Fe}^{2+}$ in a 3:1 stoichiometry to form a stable complex by the ligand exchange reaction $[9,14]$.

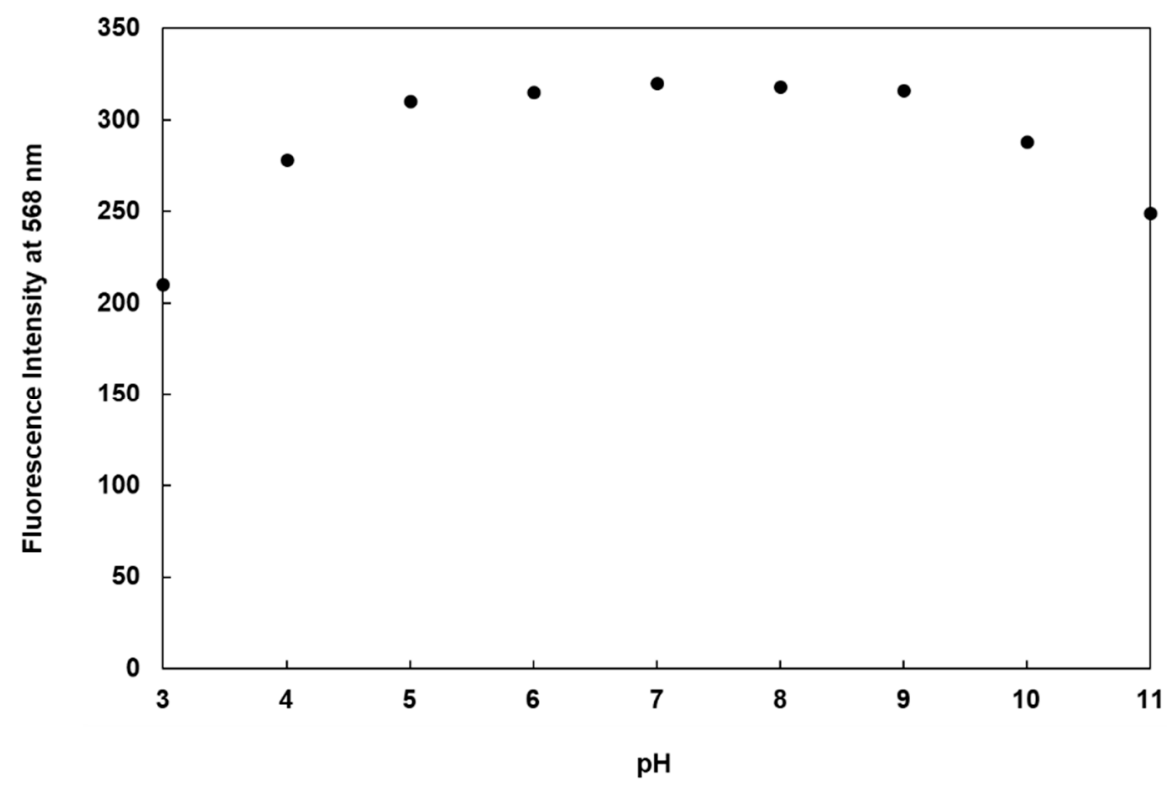

Figure 6. Fluorescence intensity of BDP- $\mathrm{Fe}^{2+}$ after the addition of dopamine in buffer at different $\mathrm{pH}$ values. $\left[\mathrm{BDP}-\mathrm{Fe}^{2+}\right]=1.0 \mu \mathrm{M}$; [Dopamine] $=5.0 \mu \mathrm{M}$; excitation wavelength, $490 \mathrm{~nm}$.

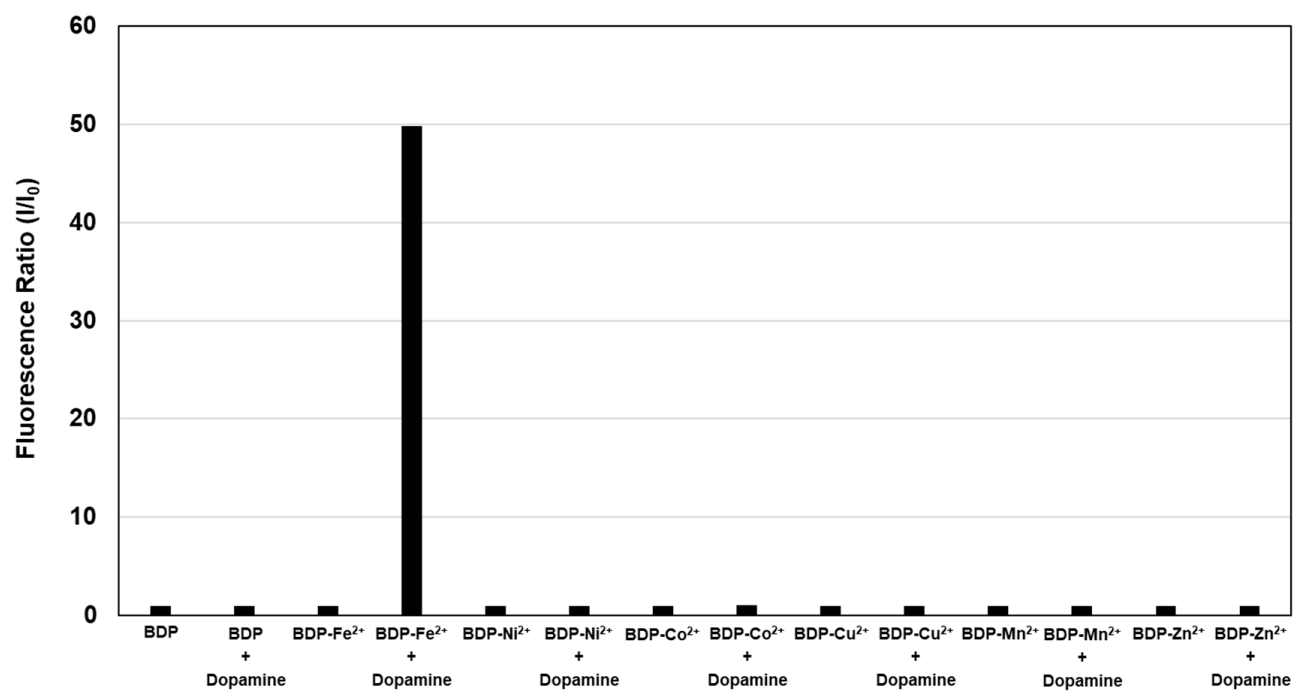

Figure 7. Fluorescence ratio of BDP and $\mathrm{BDP}_{-} \mathrm{M}^{2+}\left(\mathrm{M}=\mathrm{Fe}^{2+}, \mathrm{Ni}^{2+}, \mathrm{Co}^{2+}, \mathrm{Cu}^{2+}, \mathrm{Mn}^{2+}, \mathrm{Zn}^{2+}\right)$ at $525 \mathrm{~nm}$ before and after the addition of dopamine. $[\mathrm{BDP}]=\left[\mathrm{BDP}_{-} \mathrm{M}^{2+}\right]=1.0 \mu \mathrm{M}$; [dopamine $]=5.0 \mu \mathrm{M}$; solvent $=$ HEPES buffer solution $(\mathrm{pH} 7.0)$; excitation wavelength $=490 \mathrm{~nm}$. Y axis, I: fluorescence intensities of BDP or BDP-M ${ }^{2+}$ at $525 \mathrm{~nm}$ before and after the addition of dopamine, and $\mathrm{I}_{0}$ : fluorescence intensities of BDP or BDP-M ${ }^{2+}$ themselves at $525 \mathrm{~nm}$. 

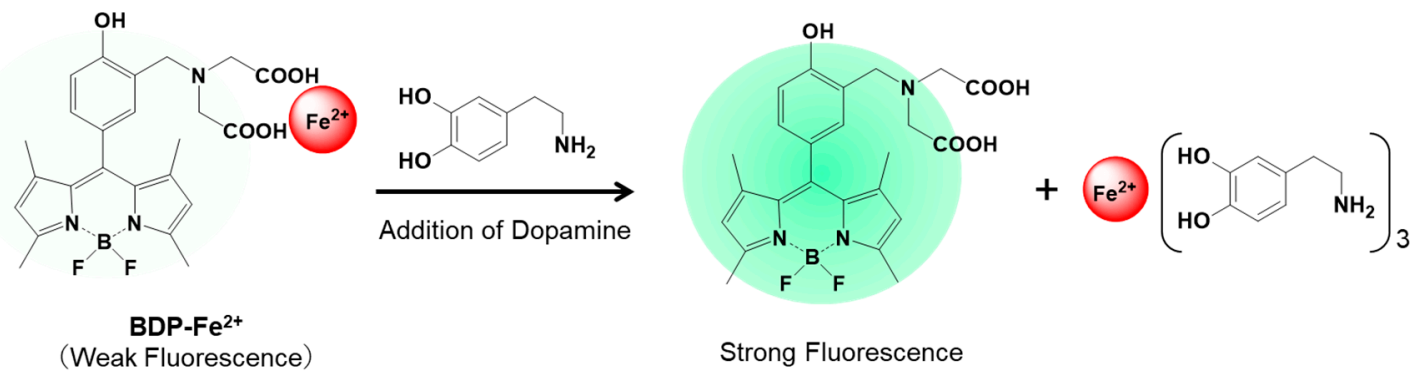

Figure 8. Schematic representation of the reaction mechanism between BDP-Fe ${ }^{2+}$ and dopamine.

Figure 9 shows the fluorescence ratio of $\mathrm{BDP}^{-\mathrm{Fe}^{2+}}$ at $525 \mathrm{~nm}$ before and after the addition of dopamine, and other foreign substances that may be present in biological samples. All the tests were carried out with a mixture of $\mathrm{BDP}-\mathrm{Fe}^{2+}$ and an excess amount of foreign substances. The fluorescence enhancement of BDP-Fe ${ }^{2+}$, when dopamine was added, was considerably larger $\left(\mathrm{I} / \mathrm{I}_{0}=49.8\right)$ than those after the addition of adrenaline (2.5), noradrenaline (2.2), serotonin (1.3), and other compounds ( 1.0). The obtained results indicated that the response of $\mathrm{BDP}-\mathrm{Fe}^{2+}$ to dopamine was unaffected by the excess amounts of other biological substances due to the release of $\mathrm{Fe}^{2+}$ from $\mathrm{BDP}-\mathrm{Fe}^{2+}$ and formation of a stable $\mathrm{Fe}^{2+}$-dopamine complex.

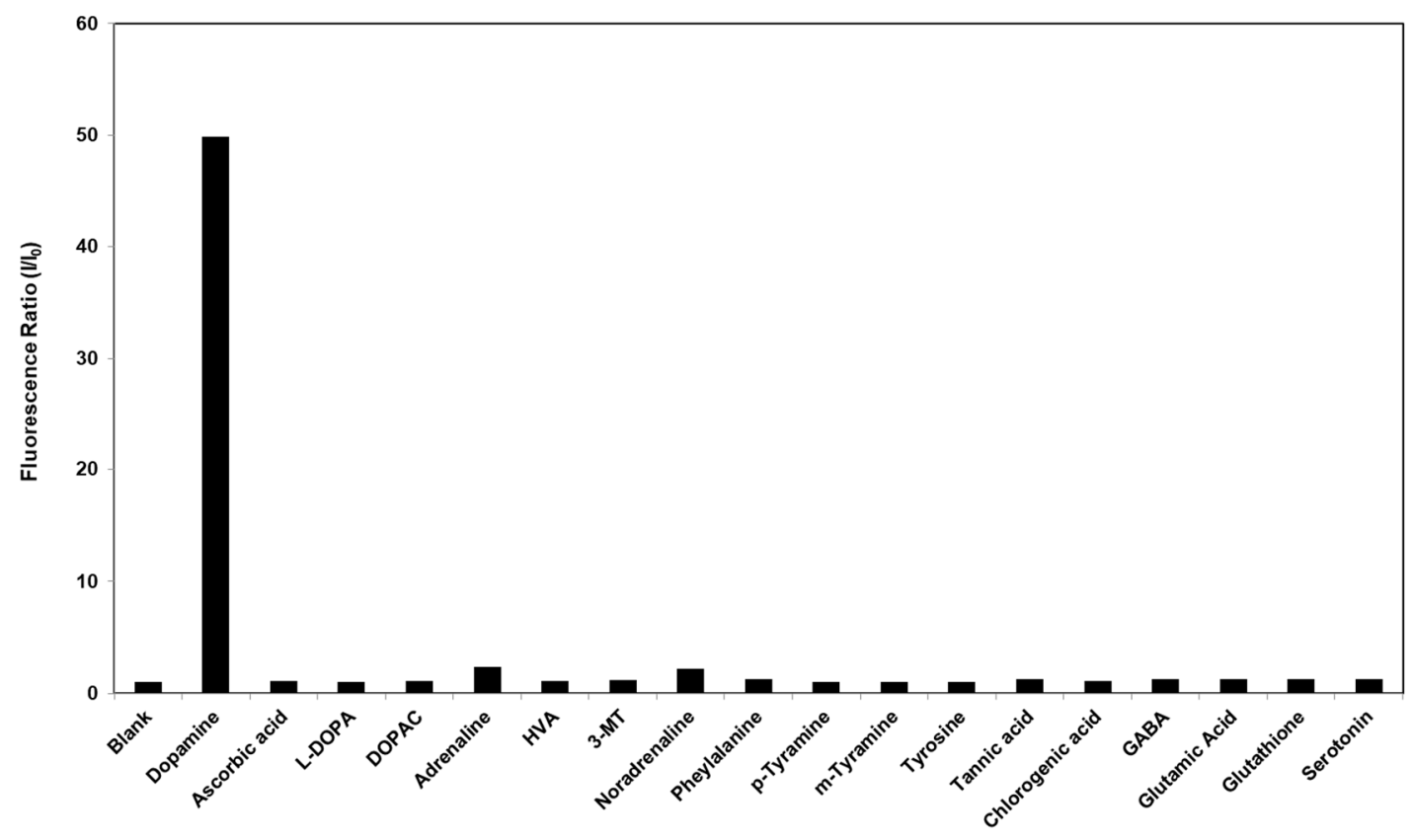

Figure 9. Fluorescence ratio of $\mathrm{BDP}-\mathrm{Fe}^{2+}$ at $525 \mathrm{~nm}$ following the addition of dopamine and various related interference compounds; $\left[\mathrm{BDP}-\mathrm{Fe}^{2+}\right]=1.0 \mu \mathrm{M}$; [interference compounds] $=5.0 \mu \mathrm{M}$; excitation wavelength $=490 \mathrm{~nm}$. $Y$ axis, I: fluorescence intensity of BDP- $\mathrm{Fe}^{2+}$ at $525 \mathrm{~nm}$ before and after addition of various amino compounds, and $\mathrm{I}_{0}$ : fluorescence intensity of $\mathrm{BDP}-\mathrm{Fe}^{2+}$ at $525 \mathrm{~nm}$.

The analytical performance of BDP-Fe ${ }^{2+}$ was compared with those of previously reported compounds (References 1 and 2) and is summarized in Table 1. BDP-Fe ${ }^{2+}$ exhibited large fluorescence enhancement upon dopamine addition, whereas the fluorescence intensities of [1] and [2] were approximately three times and ten times lower, respectively, than those of BDP-Fe ${ }^{2+}$. Thus, BDP-Fe ${ }^{2+}$ could be used to detect dopamine with greater sensitivity than in [1] and [2]. These observations indicate that the $\mathrm{BDP}$ group in $\mathrm{BDP}-\mathrm{Fe}^{2+}$ is a sensitive functional group and contributes to a larger fluorescence enhancement via ligand exchange between dopamine and $\mathrm{BDP}-\mathrm{Fe}^{2+}$, and the chemical 
structure of the fluorescent dye in the fluorescent probe plays an important role in determining the fluorescent properties.

Table 1. Comparison of BDP- $\mathrm{Fe}^{2+}$ with previously reported compounds.

\begin{tabular}{|c|c|c|c|c|c|}
\hline Assay & $\operatorname{Ex}(\mathrm{nm}) / \operatorname{Em}(\mathrm{nm})$ & Fluorescence Ratio $\left(\mathrm{I} / \mathrm{I}_{0}\right)$ * & Limit of Detection (nM) & Operation Time (min) & Reference \\
\hline BDP-Fe ${ }^{2+}$ & $496 / 525$ & 50.0 & 1.1 & 5 & - \\
\hline Reference 1 & $450 / 563$ & 12.7 & 10.0 & 5 & 19 \\
\hline Reference 2 & $350 / 445$ & 3.8 & 59.0 & 5 & 14,19 \\
\hline
\end{tabular}

* Fluorescence ratio after the addition of $5.0 \mu \mathrm{M}$ of dopamine. I: Fluorescence intensity of reagent after the addition of dopamine; $\mathrm{I}_{0}$ : fluorescence intensity of the reagent itself.

The lifetime of BDP- $-\mathrm{Fe}^{2+}$ is important for the continuous monitoring of dopamine. The BDP-Fe ${ }^{2+}$ solution was irradiated by excitation light $(490 \mathrm{~nm})$, and the fluorescence intensities were observed for $24 \mathrm{~h}$. Compared with BDP-Fe ${ }^{2+}$, the photostability of a previously reported compound containing the cyanopyranyl group [19] was observed under the irradiation of excitation light $(455 \mathrm{~nm})$ for the same period. The data are shown in Figure 10. After irradiation for $24 \mathrm{~h}$, the fluorescence ratio of BDP-Fe ${ }^{2+}$ was $\sim 98 \%$ of the original value, whereas previously reported compounds showed $\sim 64 \%$. This result indicates that $\mathrm{BDP}-\mathrm{Fe}^{2+}$ is more stable than previously reported compounds, and that this compound produces a reliable quantitative response to dopamine even after long periods of optical measurement.

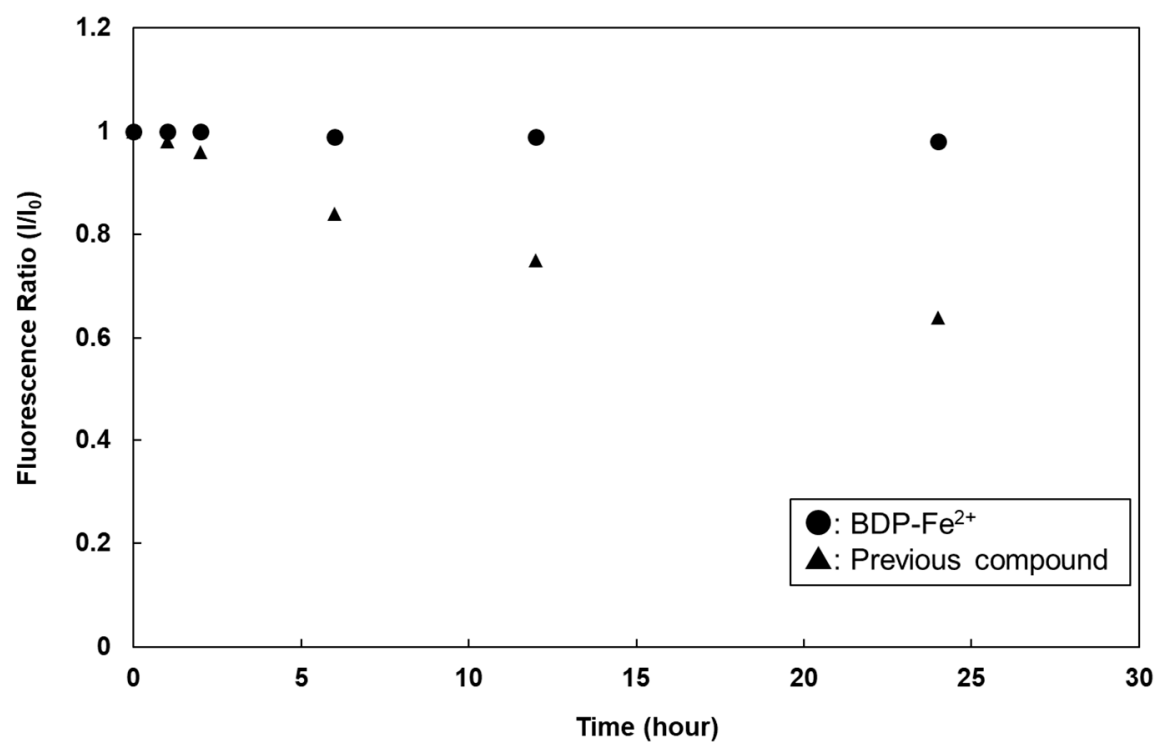

Figure 10. Fluorescence ratios of $\mathrm{BDP}-\mathrm{Fe}^{2+}$ and previously reported compounds, following the irradiation of excitation light for $24 \mathrm{~h}$; $\left[\mathrm{BDP}-\mathrm{Fe}^{2+}\right]=$ [previous compound] $=1.0 \mu \mathrm{M}$; excitation wavelength: $490 \mathrm{~nm}$ for BDP-Fe ${ }^{2+}$, and $455 \mathrm{~nm}$ for previous compound.

As an application of this assay, the detection of dopamine in human serum was conducted using BDP- $\mathrm{Fe}^{2+}$ and the results were compared with dopamine assays in HEPES buffer solution. Figure 11 shows the relationship between fluorescence intensities at $525 \mathrm{~nm}$ and dopamine concentration. The fluorescence intensity of $\mathrm{BDP}-\mathrm{Fe}^{2+}$ in human serum or in the buffer solution increased with increasing dopamine concentration, and a good linear relationship was observed. Moreover, fluorescence intensities at each dopamine concentration for assay in human serum were almost the same as those in HEPES buffer solution. Thus, BDP-Fe ${ }^{2+}$ could be used to detect dopamine with high selectivity in the presence of other substances as bovine serum albumin (BSA), inorganic salts, etc., and this assay is applicable to the detection of dopamine in the presence of impurities. 


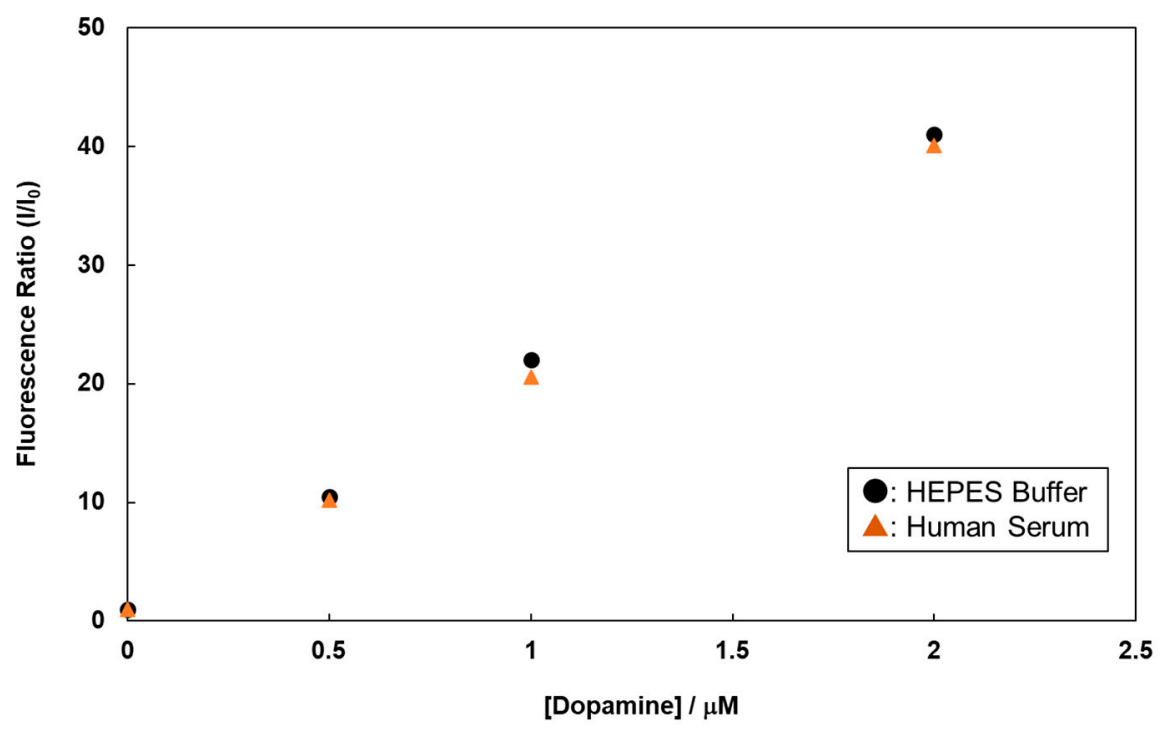

Figure 11. Fluorescence ratio of $\mathrm{BDP}-\mathrm{Fe}^{2+}$ at $525 \mathrm{~nm}$ following the addition of dopamine at different concentrations; $\left[\mathrm{BDP}-\mathrm{Fe}^{2+}\right]=1.0 \mu \mathrm{M}$; solvent = HEPES buffer solution $(\mathrm{pH} 7.0)$ or human serum; excitation wavelength $=490 \mathrm{~nm}$. $Y$ axis, I: fluorescence intensity of BDP-Fe ${ }^{2+}$ at $525 \mathrm{~nm}$ before and after addition of various amino compounds, and I0: fluorescence intensity of BDP-Fe ${ }^{2+}$ at $525 \mathrm{~nm}$.

This assay was compared with another detection method-i.e., enzyme linked immunosorbent assay (ELISA) - and the results are summarized in Table 2. ELISA is time-consuming, labor-intensive, and has a high background signal/noise ratio and low sensitivity [26]. On the other hand, the fluorescent method described here shows a higher sensitivity, wider detection range, and lower background signal. Therefore, the dopamine analysis using BDP- $\mathrm{Fe}^{2+}$ satisfies the requirements for highly sensitive, highly selective, and high-throughput assays of dopamine and can be widely used as a convenient method for dopamine detection in both research laboratories and medical applications.

Table 2. Comparison of this study with another dopamine detection method by ELISA.

\begin{tabular}{cccc}
\hline Assays & Detection Limit $(\mathbf{n M})$ & Operation Time (min) & Reference \\
\hline This study & 1.1 & 5 & - \\
ELISA & 6.1 & 70 & 26 \\
\hline
\end{tabular}

\section{Conclusions}

In the present study, a new fluorescent sensing molecule that selectively couples with dopamine and exhibits a large increase in fluorescence intensity as a result has been reported. No interference in the detection of dopamine by the presence of foreign substances has been found. In addition, the detection of dopamine in human serum was successfully performed. This assay for dopamine was not only easy to apply, but it has been proved to be rapid, highly sensitive and selective. Based on the extremely positive results of this study, further efforts are ongoing to investigate other possible indicators for the detection of various living substances.

Author Contributions: Conceptualization; design and synthesis of fluorescent reagent; investigation; writing, review, and editing: Y.S.

Funding: This research received no external funding.

Conflicts of Interest: The author declares no conflict of interest. 


\section{References}

1. Pradhan, T.; Jung, H.S.; Jang, J.H.; Kim, T.W.; Kang, C.; Kim, J.S. Chemical sensing of neurotransmitters. Chem. Soc. Rev. 2014, 43, 4684-4713. [CrossRef] [PubMed]

2. Rojas, S.; Devic, T.; Horcajada, P. Metal organic frameworks based on bioactive components. J. Mater. Chem. B 2017, 5, 2560-2573. [CrossRef]

3. Beaulieu, J.-M.; Gainetdinov, R.R. The physiology, signaling, and pharmacology of dopamine receptors. Pharmacol. Rev. 2011, 63, 182-217. [CrossRef] [PubMed]

4. Darbin, O. The aging striatal dopamine function, Parkinsonism. Relat. Disord. 2012, 18, 426-432. [CrossRef] [PubMed]

5. Grace, A.A. Dopamine system dysregulation by the Hippocampus: implications for the pathophysiology and treatment of schizophrenia. Neuropharmacology 2012, 62, 1342-1348. [CrossRef] [PubMed]

6. Gorwood, P.; Strat, Y.; Ramoz, N.; Dubertret, C.; Moalic, J.; Simonneau, M. Genetics of dopamine receptors and drug addiction. Hum. Genet. 2012, 131, 803-822. [CrossRef] [PubMed]

7. Costa, C.; Parnetti, L.; D’Amelio, M.; Tozzi, A.; Tantucci, M.; Romigi, A.; Siliquini, S.; Cavallucci, V.; Di Filippo, M.; Mazzocchetti, P. Amyloid-b Epilepsy D1 dopamine receptors: a possible pathogenetic link? Neurobiol. Aging 2016, 48, 161-171. [CrossRef] [PubMed]

8. Uhlhaas, P.J.; Singer, W. Neuronal dynamics and neuropsychiatric disorders: Toward a translational paradigm for dysfunctional large-scale networks. Neuron 2012, 75, 963-980. [CrossRef]

9. Niu, S.; Fang, Y.; Zhang, K.; Sun, J.; Wan, J. Determination of dopamine using the fluorescence quenching of 2,3-diaminophenazine. Instrum. Sci. Technol. 2017, 45, 101-110. [CrossRef]

10. Guadarrama-Flores, B.; Rodríguez-Monroy, M.; Cruz-Sosa, F.; García-Carmona, F.; Gandía-Herrero, F. Production of dihydroxylated betalains and dopamine in cell suspension cultures of Celosia argentea var. plumose. J. Agric. Food Chem. 2015, 63, 2741-2749. [CrossRef]

11. Wang, A.-J.; Feng, J.-J.; Dong, W.-J.; Lu, Y.-H.; Li, Z.-H.; Riekkola, M.-L. Spermine-graft-dextran non-covalent copolymer as coating material in separation of basic proteins and neurotransmitters by capillary electrophoresis. J. Chromatogr. A 2010, 1217, 5130-5136. [CrossRef] [PubMed]

12. Chen, X.; Chen, S.; Ma, Q. Fluorescence detection of dopamine based on nitrogen-doped graphene quantum dots and visible paper-based test strips. Anal. Methods 2017, 9, 2246-2251. [CrossRef]

13. Wang, H.Y.; Hui, Q.S.; Xu, L.X.; Gang, J.J.; Sun, Y. Fluorimetric determination of dopamine in pharmaceutical products and urine using ethylene diamine as the fluorigenic reagent. Anal. Chim. Acta 2003, 497, 93-99. [CrossRef]

14. Seto, D.; Maki, T.; Soh, N.; Nakano, K.; Ishimatsu, R.; Imato, T. A simple and selective fluorometric assay for dopamine using a calcein blue-Fe ${ }^{2+}$ complex fluorophore. Talanta 2012, 94, 36-43. [CrossRef] [PubMed]

15. Suzuki, Y.; Yokoyama, K. Design and Synthesis of Intramolecular Charge Transfer-Based Fluorescent Reagents for the Highly-Sensitive Detection of Proteins. J. Am. Chem. Soc. 2005, 127, 17799-17802. [CrossRef]

16. Suzuki, Y.; Takagi, N.; Sano, T.; Chimuro, T. Design and Synthesis of a Novel Fluorescent Protein Probe for Easy and Rapid Electrophoretic Gel Staining by using a Commonly Available UV-based Fluorescent Imaging System. Electrophoresis 2013, 34, 2464-2472. [CrossRef]

17. Suzuki, Y. Design and Synthesis of Fluorescent Probe Based on "On-Off" Behavior of Dansyl Group through Controlling Quenching Efficiency of Cyanopyranyl Group by Interaction with Proteins. Anal. Methods 2013, 5, 2174-2177. [CrossRef]

18. Suzuki, Y.; Kuno, A.; Chiba, Y. Development of fluorescent probes for "On-Off" switching based detection of lectin-saccharide interactions. Sens. Actuators B Chem. 2015, 220, 389-397. [CrossRef]

19. Suzuki, Y. Design and Synthesis of Fluorescent reagents for selective detection of dopamine. Sens. Actuators B Chem. 2016, 239, 383-389. [CrossRef]

20. Suzuki, Y. Development of a Fluorescent Peptide for the Highly Sensitive and Selective Detection of Oxytocin. Sens. Actuators B Chem. 2018, 254, 321-328. [CrossRef]

21. Suzuki, Y. Development of a Fluorescent Peptide for the Highly Sensitive and Selective Detection of Vascular Endothelial Growth Factor. Sens. Actuators B Chem. 2018, 276, 230-237. [CrossRef]

22. Schmitt, A.; Hinkeldey, B.; Wild, M.; Jung, G. Synthesis of the Core Compound of the BODIPY Dye Class: 4,4'-Difluoro-4-bora-(3a,4a)-diaza-s-indacene. J. Fluoresc. 2009, 19, 755-759. [CrossRef] [PubMed] 
23. Arroyo, I.J.; Hu, R.; Merino, G.; Tang, B.Z.; Peña-Cabrera, E. The Smallest and One of the Brightest. Efficient Preparation and Optical Description of the Parent Borondipyrromethene System. J. Org. Chem. 2009, 74, 5719-5722. [CrossRef] [PubMed]

24. Ziessel, R.; Ulrich, G.; Harriman, A. The chemistry of Bodipy: A new El Dorado for fluorescence tools. New J. Chem. 2007, 31, 496-501. [CrossRef]

25. Ulrich, G.; Ziessel, R.; Harriman, A. The chemistry of fluorescent Bodipy dyes: Versatility unsurpassed. Angew. Chem. Int. Ed. 2008, 47, 1184-1196. [CrossRef]

26. Dopamine (DA) ELISA Kit, BioVision Inc. Available online: https://www.biovision.com/documentation/ datasheets/K4219.pdf (accessed on 11 September 2019).

(C) 2019 by the author. Licensee MDPI, Basel, Switzerland. This article is an open access article distributed under the terms and conditions of the Creative Commons Attribution (CC BY) license (http://creativecommons.org/licenses/by/4.0/). 